\begin{tabular}{c|l} 
Motaice & e-ISSN: $2655-9404$ \\
Vol. 01 No. 2, Oktober 2018 & DOI: $10.20473 /$ ntr.v1i2.9283 \\
\hline
\end{tabular}

Article history: Submitted 3 October 2018; Accepted 10 October 2018; Available online 15 October 2018.

\title{
Tugas, Wewenang dan Tanggung Jawab Balai Harta Peninggalan Dalam Pemberesan Harta Pailit
}

\author{
Raisa Inayati \\ raisa.inayati@gmail.com \\ Universitas Airlangga
}

\begin{abstract}
Bankruptcy will essentially change the competent status of the relevant legal subject of the debtor in the management of the bankruptcy property, then in the process must follow certain terms and procedures so declared bankrupt based on a judge's decision. Due to the verdict of bankruptcy statement against the debtor will become a foothold of the next problem that is about how the creditors get their rights from the debtor bankruptcy and who will take care of the division of bankrupt debtors. Against this statement, Article 70 of Law Number 37 Year 2004 concerning Bankruptcy and Suspension of Obligation for Payment of Debts stipulates that the entitled to do belongs to The Orphans Chamber or other Curators. Closing up bankruptcy belongs to the end of the bankruptcy process. In this writing can be known about the main role in the management and ordering of bankrupt property carried out by the Curators / The Orphans Chamber.
\end{abstract}

Keywords: Bankruptcy; Curators; The Orphans Chamber; Bankruptcy Assets.

\begin{abstract}
Abstrak
Kepailitan pada hakikatnya akan mengubah status cakap dari subjek hukum yang bersangkutan yaitu si debitor dalam pengurusan harta pailitnya, maka dalam prosesnya harus mengikuti syarat dan prosedur tertentu sehingga dinyatakan pailit dengan berdasarkan suatu keputusan hakim. Akibat putusan pernyataan pailit terhadap debitor yang mendasar tersebut akan menjadi suatu pijakan persoalan selanjutnya yaitu mengenai bagaimana para kreditor mendapatkan hak-haknya dari debitor pailit dan siapakah yang akan mengurus pembagian harta debitor pailit tersebut. Terhadap pernyataan ini, dalam Pasal 70 Undang-Undang Nomor 37 Tahun 2004 tentang Kepailitan dan Penundaan Kewajiban Pembayaran Utang diatur bahwa yang berhak melakukan itu adalah Balai Harta Peninggalan dan kurator. Membagi harta pailit merupakan bagian akhir dari proses kepailitan. Dalam penulisan ini dapat diketahui mengenai peran utama dalam pengurusan dan pemberesan harta pailit yang dilaksanakan oleh Kurator/Balai Harta Peninggalan.
\end{abstract}

Kata Kunci: Kepailitan; Kurator; Balai Harta Peninggalan; Harta Pailit.

\section{Pendahuluan}

Dalam kehidupan sehari-hari, baik orang perorangan (natural person) maupun suat badan hukum (legal entity) guna menjalankan roda ekonomi usahanyanya selalu membutuhkan dana. Kebutuhan dana tersebut adakakalanya dapat dipenuhi dengan sendiri berdasarkan kemampuannya, namun adakalanya pula tidak dapat dipenuhi dengan sendiri. Cara yang sering dilakukan guna mengatasi kekuarangan tersebut adalah dengan melalui meminjam dari pihak yang lain. Apabila seseorang 
atau badan hukum tersebut memperoleh pinjaman dari pihak lain (orang lain atau badan hukum lain), pihak yang mendapatkan pinjaman tersebut disebut sebagai debitor sedangkan pihak yang memberikan tersebut disebut sebagai kreditor. Berdasarkan Putusan Mahkamah Agung Republik Indonesia No. 04 K/N/1999 bahwa yang dimaksud dengan utang adalah suatu hak yang dapat dinilai dengan sejumlah uang tertentu yang timbul karena perjanjian atau perikatan atau Undangundang, termasuk tidak hanya kewajiban debitur untuk membayar, akan tetapi juga hak dari kreditur menerima dan mengusahakan. Selanjutnya pada Putusan Mahkamah Agung Republik Indonesia No. 13 K/N/1999 bahwa yang dimaksud dengan utang adalah segala bentuk kewajiban untuk membayar uang tertentu baik yang timbul karena perikatan maupun karena Undang-undang.

Hubungan pinjam meminjam antara debitor dan kreditor tersebut sering kali menghadapi situasi dimana debitor tidak mampu lagi membayar utangnya yang telah disepakatinya dengan kreditor. Suatu keadaan akan semakin memburuk bilamana debitor tersebut mempunyai banyak kreditor. Hal tersebut akan menimbulkan dorongan bagi para kreditor untuk berlomba-lomba meminta pemenuhan kewajiban debitor dengan segala cara, di sisi lain hal tersebut juga dapat mendorong debitor untuk melakukan tindakan yang tidak atas itikad baik. Maka guna menghindari adanya tindakan-tindakan yang tidak baik guna melaksanakan hak dan kewajiban kreditor dan debitor tersebut dibentuklah suatu cara penyelesaiannya melalui lembaga kepailian.

Kepailitan pada hakikatnya akan mengubah status cakap dari subjek hukum yang bersangkutan yaitu si debitor dalam pengurusan harta pailitnya, maka dalam prosesnya harus mengikuti syarat dan prosedur tertentu sehingga dinyatakan pailit dengan berdasarkan suatu keputusan hakim. Akibat putusan pernyataan pailit terhadap debitor yang mendasar tersebut akan menjadi suatu pijakan persoalan selanjutnya yaitu mengenai bagaimana para kreditor mendapatkan hak-haknya dari debitor pailit dan siapakah yang akan mengurus pembagian harta debitor pailit tersebut. Terhadap pernyataan ini, dalam Pasal 70 Undang-Undang Nomor 37 Tahun 2004 tentang Kepailitan dan Penundaan Kewajiban Pembayara Utang (selanjutnya 
Undang-Undang Kepailitan) diatur bahwa yang berhak melakukan itu adalah Balai Harta Peninggalan dan kurator. Pasal 70 ayat (1) Undang-Undang Kepailitan apabila dihubungkan dengan Pasal 15 ayat (2) Undang-Undang Kepailitan diatur dalam hal debitor, kreditor atau pihak yang berwenang mengajukan permohonan pernyataan pailit sebagaimana dimaksud dalam Pasal 2 ayat (2), ayat (3), ayat (4) atau ayat (5) tidak mengajukan usul pengangkatan kurator kepada Pengadilan, maka Balai Harta Peninggalan diangkat selaku Kurator. Tugas Balai Harta Peninggalan selaku kurator tidaklah mudah, karena sering kali banya persoalan yang dihadapinya, seperti menghadapi debitor yang tidak dengan sukarela menjalankan putusan pengadilan, bahkan tetap terus bertansaksi, sehingga perlu diketahui mengenai tugas, wewenang dan tanggung jawab Balai Harta Peninggalam dalam pemberesan harta pailit.

\section{Pembahasan}

Tugas Balai Harta Peninggalan sebagai pengampu kepailitan dapat dibagi dua (Pasal 69 Undang-Undang Kepailitan), yaitu adalah pelaksanaan tugas pengurusan dan pemberesan harta pailit. Dalam melaksanakan tugas pengurusan dan pemberesan harta pailit tersebut tidak dapat dipisahkan dari ketentuan KUH Perdata sebagai sumbernya antara lain :

1. Pasal 1131 KUHPerdata yang berbunyi :

"Segala kebendaan si berhutang baik yang bergerak maupun yang tidak bergerak, baik yang sudah ada maupun yang baru akan ada dikemudian hari, mejadi tanggungan untuk segala perikatan perseorangan".

2. Pasal 1132 KUHPerdata yang berbunyi :

"Kebendaan tersebut menjadi jaminan bersama-sama bagi semua orang yang menghutangkan kepadanya, pendapatan penjualan benda-benda itu dibagi menurut keseimbangan, yaitu menurut besar kecilnya piutag masingmasing, keculai apabila diantara para berpiutang itu ada alasan yang sah untuk didahulukan".

Dari kedua pasal tersebut dapat ditarik pehamanan bahwa yang menjadi jaminan utang seorang/suatu badan, bukan hanya harta yang sudah ada saja akan tetapi yang akan ada dikemudian hari, mejadi jaminan bagi kreditor baik preferen maupun konkuren. 


\section{Tugas pengurusan yaitu:}

a. Segera setelah mendapatkan Pentetapan/Putusan Kepailitan dari Pengadilan Niaga yang termasuk dalam wilayah kerja dari Balai Harta Peninggalan yang bersangkutan, maka berdasarkan Pasal 98 Undang-Undang Kepailitan Kurator harus melaksanakan semua upaya mengamankan harta pailit dan menyimpan semua surat, dokumen, uang, perhiasan, efek dan surat berharga lainnya.

Balai Harta Peninggalan dengan persetujuan dari hakim pengawas berwenang menyewa tempat penyimpanan bagi barang-barang yang termasuk harta pailit sampai proses pengurusan dan pemberesan kepailitan berakhir, sebagaimana diatur dalam Pasal 10 Undang-Undang Kepailitan. Atas pengamanan tersebut, biaya penyewaan tempat akan dibebankan kepada harta pailt.

b. Paling lambat 2 hari setelah menerima surat putusan pengangatan sebagai kurator, harus membuat Pencatatan Harta Pailit (Pasal 100 Undang-Undang Kepailitan)

c. Paling lambat 5 hari setelah menerima Penetapan/Putusan Kepailitan dari Pengadilan Niaga yang masuk wilayah kerja Balai Harta Peninggalan bersangkutan, maka berdasarkan Pasal 15 ayat (4) Undang-Undang Kepailitan, Balai Harta Peninggalan selaku pengampu kepailitan harus mengumumkan kepailitan tersebut dalam minimal 2 surat kabar yang ditunjuk oleh Hakim Pengawas dan dalam Berita Negara RI.

Dalam pengumuman tersebut harus mencantumkan :

- Identitas debitor pailit

- Identitas Kurator

- Nama Hakim Pengawas

- Idetitas Panitia Kreditor Sementara, bila telah ditunjuk.

- Tempat dan waktu Rapat Kreditor Pertama yang dilaksankan dalam tempo maksimal 30 hari setelah putusan pailit.

- Tempat dan batas waktu pengajuan tagihan kreditor.

- Tempat dan atas waktu verfikasi pajak.

Maksud dari Pasal 15 ayat (4) Undang-Undang Kepailitan ini adalah agar bagi para pihak yang mengadakan transaksi dagang dengan debitor pailit guna segera menghentikan transaksi tersebut dan guna publisitas akan keadaaan 
debitor pailit yang dapat diketahui para kreditornya dimana pun berada.

d. Mengadakan/membuat pencatatan/pendaftaran harta kekayaan dari debitor pailit dan memisah-misahkan barang yang cepat rusak karena barang-barang yang cepat rusak/busuk akan dapat dijual secepatnya sebelum adanya rapat verifikasi dengan catatan mendapatkan persetujuan dari hakim pengawas.

e. Memangggil debitor pailit guna meminta keterangan sebab-sebab menjadi pailit, lalu mengenai status perkawinan sah atau tidak, usaha apa yang dijalankan debitor pailit dan kemungkinan untuk dapat dilanjutkannya usaha tersebut dan sebagainya.

f. Mengirim surat kepada Kantor surat-surat yang beralamat kepada debitor pailit dapat diberikan kepada Kurator/Bali Harta Peninggalan guna seterusnya diberikan kepada :

1. Bank-bank yang bersangkutan;

2. Lurah setempat;

3. Kantor pajak domisili yang bersangkutan;

4. Asuransi.

g. Memanggil kredior/debitor pailit guna menagih/membayar utang-hutangnya dengan membawa bukti-bukt tagihan atau utang-utang.

h. Membuat daftar kreditor/debitor sementara.

i. Mengajukan kepada Hakim Pengawas mengenai tempat dan waktu rapat verifikasi. Rapat tersebut dipimpin oleh Hakim Pengawas dan didampingi oleh Balai Harta Peninggalan selaku pengampu kepailitan. Rapat verifikasi merupakan rapat pencocokan utang piutang yang mempunyai maksud membicarakan mengenai tata cara pembagian dan pemberesan harta pailit, serta memungkinkan pula dilakukannya pencocokan piutang bagi kreditor yang memasukkan piutangnya telah lewat waktu yang sudah ditentukan. Agar pelaksanaan rapat verifikasi ini berjalan sesuai rencana, maka kurator harus mengumumkannya minimal dalam 2 surat kabar, serta hakim pengawas harus menetapkan jangka waktu rapat dengan panggilan, paling singkat 14 hari (Pasal 187 Undang-Undang Kepailitan)Dalam rapat verifikasi/pencocokan piutang Hakim Pengawas wajib menawarkan pembentukan panitia kreditor tetap (Pasal 
80 ayat (1) Undang-Undang Kepailitan). Apakah debitor mengajukan rencana perdamaian atau tidak, karena dalam hal ini debitor berhak mengajukan rencana perdamaian (Pasal 144 Undang-Undang Kepailitan).

j. Apabila keadaan telah benar bahwa terjadi insolvensi, maka Balai Harta Peninggalan dapat membuat suatu daftar tetap atas utang-utang/piutang yang diakui/diterima dan daftar ini harus disahkan oleh Hakim Pengawas, yang kemudian akan diumumkan di Pengadilan serta Kantor Balai Harta Peninggalan.

k. Mengajukan permohonan kepada Hakim Pengawas agar dapat menjual secara lelang maupun di bawah tangan harta kekayaaan debitor pailit. Apabila cara penjualan yang ditempuh adalah secara dibawah tangan maka penjualan tersebut harus berpedoman kepada harga yang ditentukan oleh tim penaksir yang terdiri dari 4 instansi yaitu Balai Harta Peninggalan, Pengadilan Negeri setempat, Badan Pertanahan sepanjang mengenai tanah dan Direktorat Tata Bangunan (PU) sepanjang hal tersebut mengenai banguan (sesuai dengan Surat Keputusan Menteri Kehakiman RI No. M 47. PR. 09. 03 Tahun 1987).

\section{Tugas Pemberesan}

Setelah dilakukannya tugas pengurusan, maka selanjutnya tahapan yang dilakukan adalah pemberesan. Pemberesan hanya dapat dilakukan apabila: ${ }^{1}$

a) perdamaian tidak diajukan;

b) perdamaian diajukan tetapi tidak disetujui atau tidak diterima oleh kreditorkreditor yang mempunyai hak suara;

c) perdamaian diajukan, disetujui atau diterima para kreditor yang mempunyai hak suara, tetapi tidak disahkan atau tidak dihomologasi oleh hakim.

d) upaya hukum tidak dikabulkan, perdamaian tidak diajukan;

e) upaya hukum tidak dikabulkan, perdamaian tidak diterima;

f) upaya hukum tidak dikabulkan, perdamaian diterima tetapi tidak mendapat pengesahan dari hakim.

Tugas pemberesan erat kaitannya dengan adanya penjualan atas harta

1 H. Man S. Sastrawidjaja, 2006, Hukum Kepailitan dan Penundaan Kewajiban Pembayaran Utang, PT Alumni, Bandung, Hlm.187 
kekayaan debitor pailit. Penjualan dapat dilakukan dengan cara lelang/secara dibawah tangan dengan lebih dahulu mendapatkan izin dari Hakim Pengawas (Pasal 185 ayat (2) Undang-Undang Kepailitan. Izin tersebut harus merupakan sebuah penetapan sekaligus menyumpah juru taksir yang jumlahnya 4 orang untuk barang tetap, sedangkan untuk penaksiran barang bergerak tidak perlu disumpah oleh hakim, karena setiap pegawai Balai Harta Peninggalan yang sudah memenuhi syarat dapat dimajukan guna menjadi juru taksir tetap kepada Pemerintah Daerah (oleh Sekwilda setempat).

Balai Harta Peninggalan dalam melakukan penjualan budel pailit debitor ditempuh dengan cara menjualnya secara lelang, yang sebelumnya telah dilakukan penilaian atas nilai objek lelang oleh tim penaksir dan dilakukan berdasarkan ketentuan perundang-undangan. Namun, apabila dalam proses lelang tersebut budel pailit yang ditawarkan tidak laku, maka kurator akan mengambil tindakan penjualan dibawah tangan yang berasar izin dari hakim pengawas.

Kurator dalam hal menjual harta pailit harus dengan pertimbangan alasanalasan sebagai berikut:

1. Untuk menututupi ongkos kepailitan

Pengalihan harta pailit guna menutupi ongkos-ongkos kepailitan harus dilakukan atas persetujuan hakim pengawas, dan dapat dilakukan begitu dijatuhkannya putusan pailit atas debitor meskipun masih adanya upaya hukum kasasi ataupun peninjauan kembali (Pasal 107 Undang-Undang Kepailitan)

2. Penahanan barang mengakibatkan kerugian

Pengalihan harta pailit juga dimugkinkan apabila dilakukan penahanan atas harta tersebut akan menimbulkan kerugian. Misalnya, jika barang tersebut menjadi busuk atau ongkos penyimpanannya terlalu besar. Atas pengalihan tersebut harus berdasar pada pada persetujuan hakimpengawas dan dapat dilakukan begitu dijatuhkannya putusan pailit atas debitor meskipun masih adanya upaya hukum kasasi atau peninjauan kembali.

3. Kurator menjual barang jaminan utang dalam masa penangguhan eksekusi jaminan utang. 
Berdasarkan Pasal 56 Undang-Undang Kepailitan, pihak kreditor separatis tidak diperkenankan mengeksekusi jaminan utangnya dalam masa penangguhan eksekusi dalam waktu palig lama 90 hari.Akan tetapi, kurator boleh menggunakan (dengan membebaska agunan vide Pasal 59 ayat (3) Undang-Undang Kepailitan) bahkan menjual harta pailit yang merupakan harta yang dijadikan jaminan utang tersebut apabila memenuhi syarat-syarat berikut ini :

a. Harta tersebut berada dalam kekuasaan kurator;

b. Dilakukan dalam rangka kelangsungan usaha debitor;

c.Telah diberikan perlindungan yang wajar kepada kepentingan kreditor separatis yang bersangkutan atau kepada kepetingan pihak ketiga yang mempunyai hak atas tersebut (Pasal 56 ayat (3) Undang-Undang Kepailitan). ${ }^{2}$

4. Barang yang tidak diperlukan untuk kelangsungan usaha dapat dijual.

Apabila tidak adanya usul atau ditolaknya pengesahan perdamaian, dapat diusulkan untuk melanjutkan kegiatan perusahaan debitor (Pasal 179 ayat (1) jo. Pasal 181 ayat (1) Undang-Undang Kepailitan. Dalam hal melajutkan usaha debitor ini, kurator boleh menjual harta-harta debitor pailit yang tidak diperlukan dalam melanjutkan perusahaan tersebut (Pasal 184 ayat (2) UndangUndang Kepailitan). Penjualan dalam hal ini bahkan tidak memerlukan izin siapa-siapa, sungguhpun konsultasi dengan hakim pengawas selalu dianjurkan. ${ }^{3}$ Namun apabila kegiatan melajutkan usaha debitor yang memerlukan persetujuan panitia kreditor sebagaimana diatur dalam Pasal 104 ayat (1) Undang-Undang Kepailitan, kurator wajib memperoleh izin dari hakim pengawas terlebih dahulu.

\section{Tanggung Jawab Balai Harta Peninggalan dalam Tugas Pengurusan dan Pemberesan Harta Pailit.}

Balai Harta Peninggalan sebagai pengampu kepailitan atau kurator mempunyai tugas yang cukup berat, yaitu melakukan pengurusan dan pemberesan harta pailit.

2 Munir Fuady, 2005, Hukum Pailit dalam Teori dan Praktek, PT. Citra Aditya Bakti, Bandung, Hlm. 55

3 Munir Fuady, Ibid. 
Oleh karena itu, Balai Harta Peninggalan juga mempunyai tanggung jawab yang cukup berat atas tugas pengurusan dan pemberesan yang dilakukannya. Segala perbuatan hukum yang dilakukan Balai Harta Peninggalan dalam menjalankan tugas pengurusan dan pemberesan harta pailit tidak dapat dipulihkan atau mengikat kepada seluruh pihak yang terkait, meskipun daam hal putusan pernyataan pailt tersebut dibatalkan sebagai akibat dari kasasi atau peninjauan kembali (Pasal 17 ayat (2) Undang-Undang Kepailitan).

Kurator mempunyai dua kewajiban hukum dalam melaksanakan tugas dan kewenangannya. Kewajiban yang pertama adalah mengemban statutory duties yang diatur dalam Undang-Undang Kepailitan, lalu yang kedua adalah kurator mengemban fudicary duties atau fiduciary oblogations. Fiduciary duties kurator adalah terhadap: ${ }^{4}$ Pengadilan (dalam hal Undang-Undang Kepailitan Indonesia diwakili oleh hakim pengawas); Debitor pailit; Para kreditor dan Para pemegang saham.

Dengan kata lain, Balai Harta Peninggalan sebagai kurator mengemban kepercayaan dari pengadilan, debitor, para kreditor dan para pemegang saham untuk melaksanakan tugasnya dengan sebaik-baiknya demi kepentingan para pihak tersebut. Fiduciary realtionship antara Balai Harta Peninggalan sebagai kurator dengan para pihak dalam kepailitan, maka mewajibkan kurator untuk melakukan tugas pengurusan dan pemberesan harta pailit dengan penuh tanggung jawab. Setiap perbuatan kurator yang merugikan harta pailit, baik secara disengaja maupun tidak disengaja maka kurator harus dapat mempertanggungjawabkan perbuatannya tersebut.

\section{Tanggung Jawab Balai Harta Peninggalan dalam Melaksanakan Tugas Pengurusan Harta Pailit}

Dalam tugas pengurusan harta pailit, Balai Harta Peninggalan selaku kurator dapat melakukan tindakan guna melanjutkan usaha debitor demi meningkatkan nilai dari harta pailit yang ada. Namun dalam usahanya tersebut, Balai Harta Peninggalan selaku kurator dituntut profesional yang sangat tinggi agar kegiatan melanjutkan

4 Sutan Remy Sjahdeini, Op Cit, Hlm. 228 
usaha tersebut tidak menimbulkan kerugian bagi harta pailit. Jika dalam hal Balai Harta Peninggalan sebagai pengampu kepailitan lalai atau melakukan kesalahan daam menjalankan tugasnya, maka berdasarkan Pasal 80 Stbl 1872 No.166 Balai Harta Peninggalan bertanggung jawab atas kerugian pada harta pailit yang diambil dari harta Balai Harta Peninggalan, dan akan timbul hak negara guna menuntut ganti rugi kepada pegawai Balai Harta Peningggalan yang melakukan kesalahan atau lalai tersebut. Atas kesalahan atau kelalaian yang tidak menimbulkan kerugian pada harta pailit, maka sanksi yang dijatuhkan adalah berupa teguran dan/atau sampai dengan pemberhentian tugasnya sebagai kurator.

\section{Tanggung Jawab Balai Harta Peninggalan dalam Melaksanakan Tugas Pemberesan Harta Pailit}

Berdasarkan Pasal 72 Undang-Undang Kepailitan, Kurator bertanggung jawab terhadap kesalahan atau kelalaiannya dalam melaksanakan tugas pengurusan dan pemberesan yang menyebabkan kerugian bagi harta pailit. Sehubungan dengan hal tersebut, maka kurator dapat digugat dan wajib membayar ganti kerugian apabila karena kesalahan atau kelalaiannya telah menyebabkan para pihak, khususnya kreditor konkuren dirugikan. Kerugian itu terutama apabila harta pailit berkurang nilainya sehingga dengan demikian para kreditor konkuren memperoleh nilai pelunasan tagihannya kurang dari seyogianya diterima dari hasil penjualan harta paikit seandainya nilai harta pailit tidak mengalami pengurangan sebagai akibat perbuatan kurator. ${ }^{5}$

Tugas pemberesan yang erat kaitannya dengan penjualan dan pembagian harta pailit menimbulkan tanggung jawab yang besar kepada Balai Harta Peninggalan selaku kurator agar terjadi keseimbangan dalam memenuhi kepentingan yang berbeda-beda para pihak dalam kepailian.

Jerry Hoff dengan tegas mengungkapkan bahwa terhadap kerugian yang timbul sebagai akibat dari tindakan kurator bisa menjadi tanggung jawab pribadi

\footnotetext{
5 Sutan Remy Sjahdeini, Op Cit, Hlm.223
} 
kurator, yang berarti menjadi beban harta pribadii kurator untuk mengganti kerugian tersebut. Di sisi lain kerugian yang muncul sebagai akibat atas bertindak atau tidaknya kurator dibebankan pada harta pailit untuk mengganti kerugian tersebut. ${ }^{6}$

1. Tanggung Jawab Kurator dalam Kapasitas Kurator

Tanggung jawab kurator dalam kapasitas sebagai kurator dibebankan pada harta pailit, dan bukan pada kurator secara pribadi yang harus membayar kerugian. Pihak yang menuntut mempunyai tagihan atas harta kepailitan, dan tagihannya adalah utang harta pailit, seperti : kurator lupa untuk memasukkan salah satu kreditor dalam rencana distribusi; kurator menjual aset debitor yang tidak termasuk dalam harta kepailitan; kurator menjual aset pihak ketiga; kurator berupaya menagih tagihan debitor yang pailit dan melakukan sita atas properti debitor, kemudian terbukti bahwa tuntutan debitor itu palsu. Kerugian yang timbul sebagai akibat dari tindakan kurator tersebut diatas tidaklah menjadi beban harta pribadi kurator melainkan menjadi beban harta pailit.

2. Tanggung Jawab Pribadi Kurator

Kerugian yang muncul sebagai akibat dari tindakan atau tidak bertindaknya kurator menjadi tanggung jawab kurator. Dalam hal ini kurator bertanggung jawab secara pribadi. Kurator harus membayar sendiri kerugian yang ditimbulkannya. Tanggung jawab ini dapat terjadi, misalnya, jika kurator menggelapkan harta kepailitan. Apabila kerugian yang timbul adalah akibat dari kelalaian atau karena tidak profesionalnya kurator, maka akan menjadi tanggung jawab kurator secara pribadi. Oleh karena itu kerugian tersebut tidak dibebankan pada harta pailit.

\section{Kesimpulan}

Berdasarkan hasil penelitian, dapat ditarik kesimpulan tugas, wewenang dan tanggung jawab Balai Harta Peninggalan selaku kutrator dalam melakukan tugas pengurusan dan pemberesan harta pailit dimulai sejak tanggal putusan pailit diucapkan meskipun terhadap putusan tersebut diajukan kasasi atau peninjauan

\footnotetext{
${ }^{6}$ Imran Nating, Op Cit, Hlm. 116-117
} 
kembali. Adapun tugas dan wewenang kurator dalam tahap pengurusan harta pailit yaitu mengumumkan putusan Pengadilan Niaga dalam 2 (dua) surat kabar harian dan Berita Negara RI, membuat daftar harta kekayaan pailit.pendaftaran budel pailit, memanggil para kreditor untuk medaftarkan tagihannya serta mengadakan rapat pencocokan piutang/rapat verifkasi. Sedangkan tugas dan wewenang dalam tahap pemberesan harta pailit yaitu melakukan penagihan atas piutang-piutang debitor pailit, melakukan penjualan atas harta kekayaan debitor pailit, membuat daftar pembagian, melakkan pembayaran terhadap kreditor yang diakui dalam daftar pembagian, mengumumkan berakhirnya kepailitan dalam 2 (dua) surat kabar harian dan Berita Negara RI, memberikan laporan pertanggungjawaban kepada hakim pengawas dan menyerahka buku dan dokumen mengenai harta pailit kepada debitor. Mengenai tanggung jawab kurator Balai Harta Peninggalan dalam pelaksanaan tugas pengurusan dan pemberesan yaitu apabila melakukan kelalaian atau kesalahan yang menimbulkan kerugian harta pailit, dan terdapat tuntutan dari debitor dan/atau para kreditor, maka Balai Harta Peninggalan bertanggung jawab atas kerugian yang dialami sebagaimana yang diatur dala Pasal 80 Stbl 1872 No.166 tentang Instruksi untuk Balai Harta Peninggalan, dan atas hal tersebut meniimbulkan hak Negara untuk menuntut ganti rugi kepada pegawai Balai Harta Peninggalaan yang lalai.

\section{Daftar Bacaan}

\section{Buku}

Hartono, Siti Soemarti, 1981, Pengantar Hukum Kepailitan dan Penundaan Pembayaran, Seksi Hukum Dagang Fakultas Hukum UGM, Yogyakarta.

Harahap, M. Yahya, 2011, Hukum Perseroan Terbatas, Sinar Grafika, Jakarta Jono, 2010, Hukum Kepailitan, Sinar Grafika, Jakarta.

Mudani, I Nengah, 2012, Sejarah Tugas dan Fungsi Balai Harta Peninggalan dan Hubungan dengan Instansi Terkait, Balai Harta Peninggalan, Semarang.

Muljadi, Kartin dan Gunawan Widjaja, 2003, Pedoman Menangani Perkara Kepailitan, PT Rajagrafindo Persada, Jakarta. 
Nating, Imran, 2004, Peranan dan Tanggung Jawab Kurator dalam Pengurusan dan Pemberesan Harta Pailit, PT Rajagrafindo Persada, Jakarta.

Sinaga, Syamsudin M., 2012, Hukum Kepailitan Indonesia, PT Tatanusa, Jakarta.

Sjahdeini, Sutan Remy, 2010, Hukum Kepailitan, PT Pustaka Utama Grafiti, Jakarta.

Soekanto, Soerjono, 1984, Pengantar Penelitian Hukum, UII Press, Yogyakarta.

Waluyo, Bernadette, 1999, Hukum Kepailitan dan Penundaan Kewajiban Pembayaran Utang, Mandar Maju, Bandung.

\section{Karya Ilmiah}

Sunarmi, 2004, Perbandingan Sistem Hukum Kepailita Indonesia (Civil Law System) dengan Amerika Serikat (Common Law System), Fakultas Hukum Universitas Sumatera Utara

\section{Perundang-undangan}

Kitab Undang-Undang Hukum Dagang.

Kitab Undang-Undang Hukum Perdata.

Undang-undang Republik Indonesia Nomor 37 tahun 2004 tentang Kepailitan Dan Penundaan Kewajiban Pembayaran Utang.

HOW TO CITE: Raisa Inayati, ‘Tugas, Wewenang Dan Tanggung Jawab Balai Harta Peninggalan Dalam Pemberesan Harta Pailit' (2018) Vol. 1 No. 2 Notaire. 
--Halaman ini sengaja dibiarkan kosong-- 